\title{
Rational Design of 0D, 1D and 3D Open Frameworks based on Tetranuclear Lanthanide(III) Sulfonate-Phosphonate Clusters
}

Zi-Yi Du, Hai-Bing Xu and Jiang-Gao Mao*

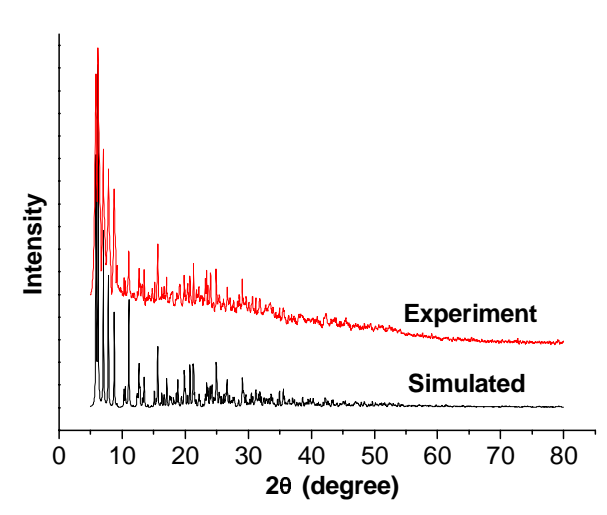

(a)

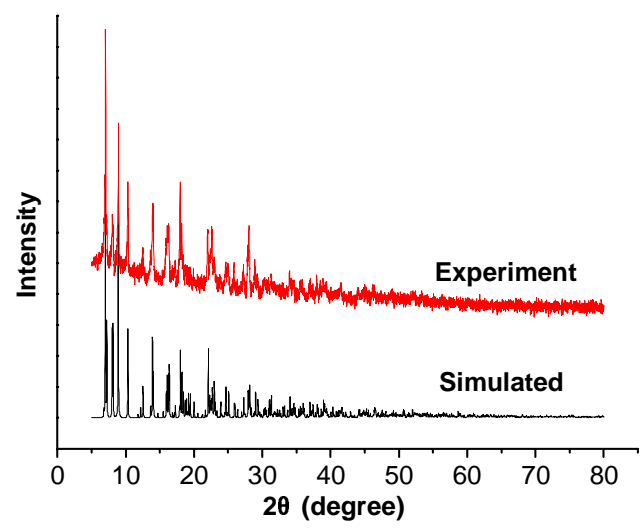

(c)

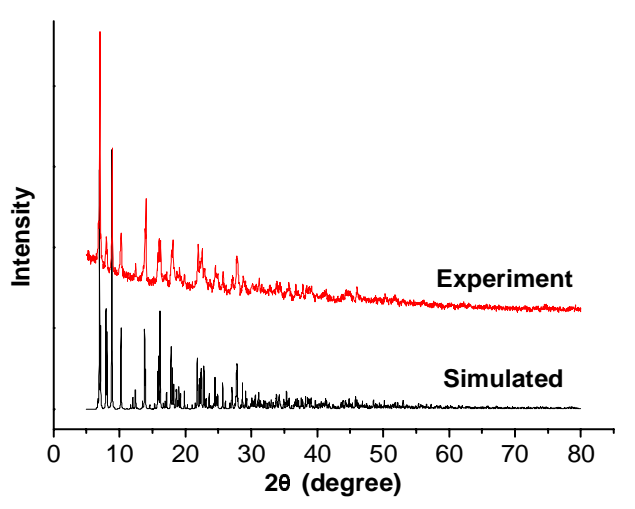

(b)

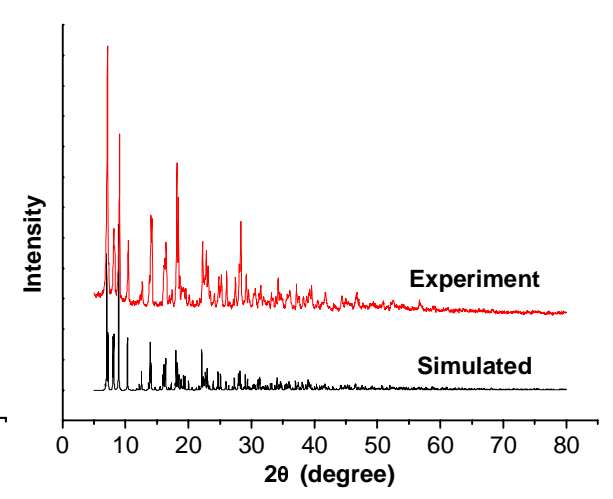

(d) 


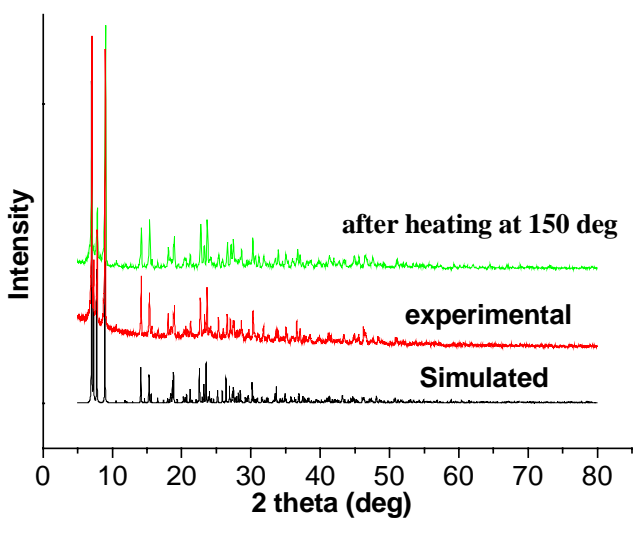

(e)

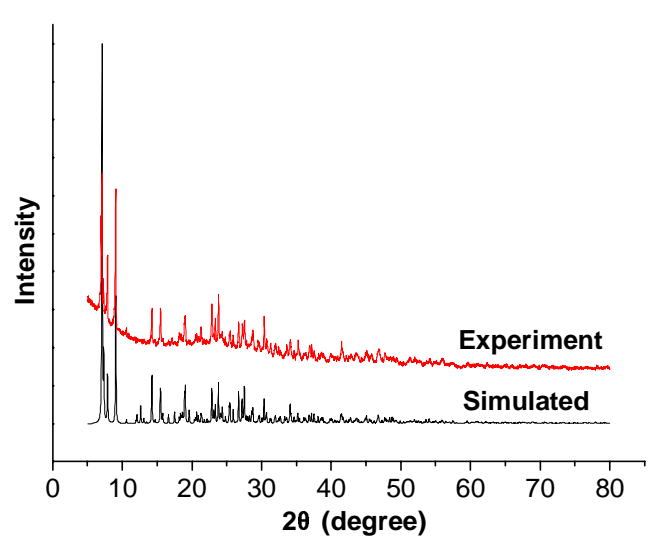

(f)

Figure S1. Simulated and experimental XRD powder patterns for compounds 1 (a), 2

(b), 3 (c), 4 (d), 5 (e) and 6 (f). 